\title{
Occurrence of endoparasites in heifers imported to Poland from the Netherlands (Short Communication)
}

\author{
BOGUMIŁA PILARCZYK, ALEKSANDRA BALICKA-RAMISZ, WOJCIECH KOZAK and \\ ALOJZY RAMISZ
}

Department of Animal Hygiene and Prophylaxis, Agricultural University Szczecin, Poland

\begin{abstract}
Prevalence of gastrointestinal parasites was studied in 106 heifers imported to Poland from the Netherlands. Prevalence of gastrointestinal nematodes and Eimeria protozoans was determined from coproscopic examinations using Willis-Schlaf flotation. The species composition of coccidia was determined from morphological characters and the time of oocyst sporulation. Fluke liver eggs were detected by decantation. The study showed the mean prevalence of Eimeria protozoans in the heifers imported from the Netherlands to Poland to be $17.92 \%$; the mean prevalences of Cryptosporidium sp. (11.32\%), gastrointestinal nematodes (55.66\%) and Fasciola hepatica (32.08\%), respectively. The following 6 coccidia species were isolated from faecal samples: E. bovis, E. aubernensis, E. ellipsoidalis, E. subspherica, E. zürni, and E. brasiliensis. The prevalence of gastrointestinal parasites in the cattle imported from the Netherlands to Poland was very high, therefore it is purposeful to mandatorily examine the imported cattle for the presence of those parasites.
\end{abstract}

Keywords: heifers, Cryptosporidium sp., Eimeria, gastrointestinal nematodes, Fasciola hepatica

\section{Zusammenfassung}

\section{Prävalenz des Innenparasitenbefalls bei nach Polen} importierten niederländischen Färsen (Kurzmitteilung)

Die Untersuchungen über den Innenparasitenbefall des Verdauungskanals mit Nematoden und Kokzidien erfolgten bei 106 nach Polen importierten niederländischen Färsen mit Hilfe der Willis-Schlaf-Methode. Die Differezierungskriterien der Eimeriaarten wurden auf Grund der Oozystenform und der Sporulationszeit festgestellt. Die Leberegeleier wurden mit der Sedimentationsmethode ermittelt. Die Prävalenz von Eimeria betrug 17,92 \%, Cryptosporidium sp. fanden sich bei $11,37 \%$, gastrointestinal Nematoden bei $55,66 \%$ und Fasciola hepatica bei $32,32 \%$ der Probanden. Sechs Kokzidienarten wurden im Kot der holländischen Färsen nachgewiesen. (E. bovis, E. aubernensis, E. ellipoidalis, E. subspherica, E. zürni und E. brasiliensis). Die Prävalenz von Parasiten des Verdauungskanals der aus den Niederlanden importierten Tiere war sehr hoch weshalb eine Untersuchung auf Parasitenbefall importierter Tiere dringend empfohlen wird.

Schlüsselwörter: Färsen, Cryptosporidium sp., Eimeria, Nematoden, Fasciola hepatica 


\section{Introduction}

Parasitoses belong to the most common diseases of ungulates (DISTL 2001, GÓRSKI et al. 2004a, 2004b, AGNEESSENS et al. 2000, BORGSTEEDE et al. 1998, 2000, MEKROUD et al. 2004, PILARCZYK et al. 2002, HILGENSTOCK et al. 2006) and result in high losses caused mainly by reduced condition, productivity, and resistance of the affected animals. Parasitic diseases proceed usually subclinically, for which reason they very often go undetected by breeders and veterinarians alike. The Black-White cattle are the commonest breed in Poland, improved by admixture of genes of the Holstein-Friesland cattle imported from Germany and the Netherlands, heifers being most frequently imported. The absence of control makes it possible to introduce, with the imported cattle, of new parasites. The problem of parasitic infestations (with protozoans and worms) of heifers imported to the Czech Republic from Germany, France, Denmark, and the Netherlands was discussed by PAVLÁSEK (1995).

At present, the cattle imported to Poland do not have to be examined for the presence of endoparasites such as coccidia, cryptosporidia, gastrointestinal nematodes, and liver fluke.

This study was aimed at identification of parasitic fauna in heifers imported to Poland from the Netherlands.

\section{Material and methods}

Coproscopic examination was carried out in 106 Holstein-Friesland heifers imported from the Netherlands - Overijssel Province to the Porta-Agra farm in Poland. During the 2-week quarantine, the heifers were fed Triticale flakes, corn silage, barley hay silage, and hay; the heifers had access to water and salt.

The prevalence of gastrointestinal nematodes and Eimeria protozoans was estimated from coproscopic examination, performed with the Willis-Schlaf flotation technique (ZIOMKO and CENCEK 1995). The samples for study were taken individually from rectum of each animal. Coccidia were identified to species using the key published by PELLERDI (1974). Examinations were supplemented by culturing oocysts at $24-26^{\circ} \mathrm{C}$ in a humid chamber, with $2.5 \%$ aqueous solution of potassium dichromate $\left(\mathrm{K}_{2} \mathrm{Cr}_{2} \mathrm{O}_{7}\right)$ to prevent mould growth.

Nematodes were identified to species based on larval culture carried out as recommended by Baermann (GUNDŁACH et al. 2004).

Faeces were examined for the presence of Cryptosporidium sp. using a modified ZiehlNeelsen staining technique (ANONYMUS 1991) and a commercially available immunoenzymatic microplate assay (PrpSpecT Cryptosporidium Microplate Assay, Alexon Inc.). The microplate assay was performed as specified by the manufacturer.

The liver fluke was detected by decantation (ZIOMKO and CENCEK 1995).

\section{Results}

The mean prevalence of gastrointestinal parasites in the heifers imported to Poland was $83.96 \%(n=89)$. 
The mean prevalence of Eimeria infestation of the heifers examined was $17.92 \%(n=19)$. As shown by coproscopy, the heifers were infested by a mix of coccidia, the following 6 coccidia species being isolated from faecal samples: E. bovis, E. aubernensis, E. ellipsoidalis, E. subspherica, E. zürni, and E. brasiliensis. The dominant species was E. bovis (Figure 1).

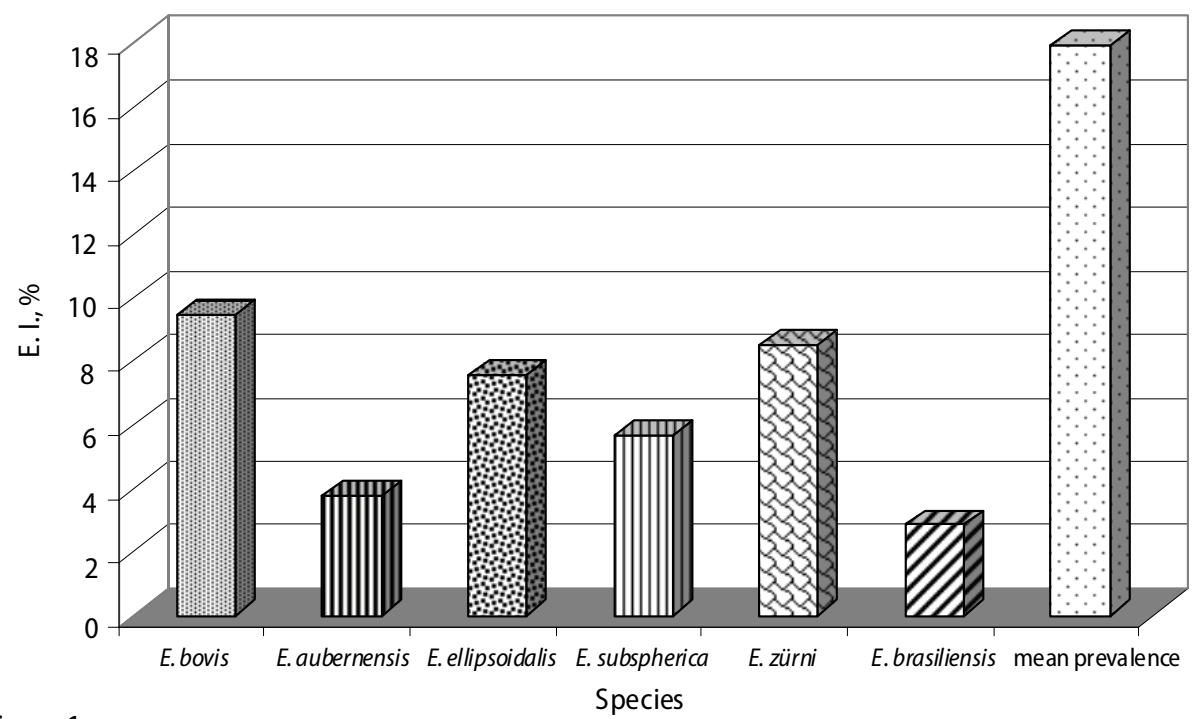

Figure 1

Prevalence of Eimeria species invasion in heifers

Prävalenz der verschiedenen Eimeriaarten bei untersuchten Färsen

In most cases $(84.21 \%, n=16)$, the coccidia-infested animals were affected by one- and two-species invasions. The maximum number of coccidia species found in the heifers was 4 (Figure 2).

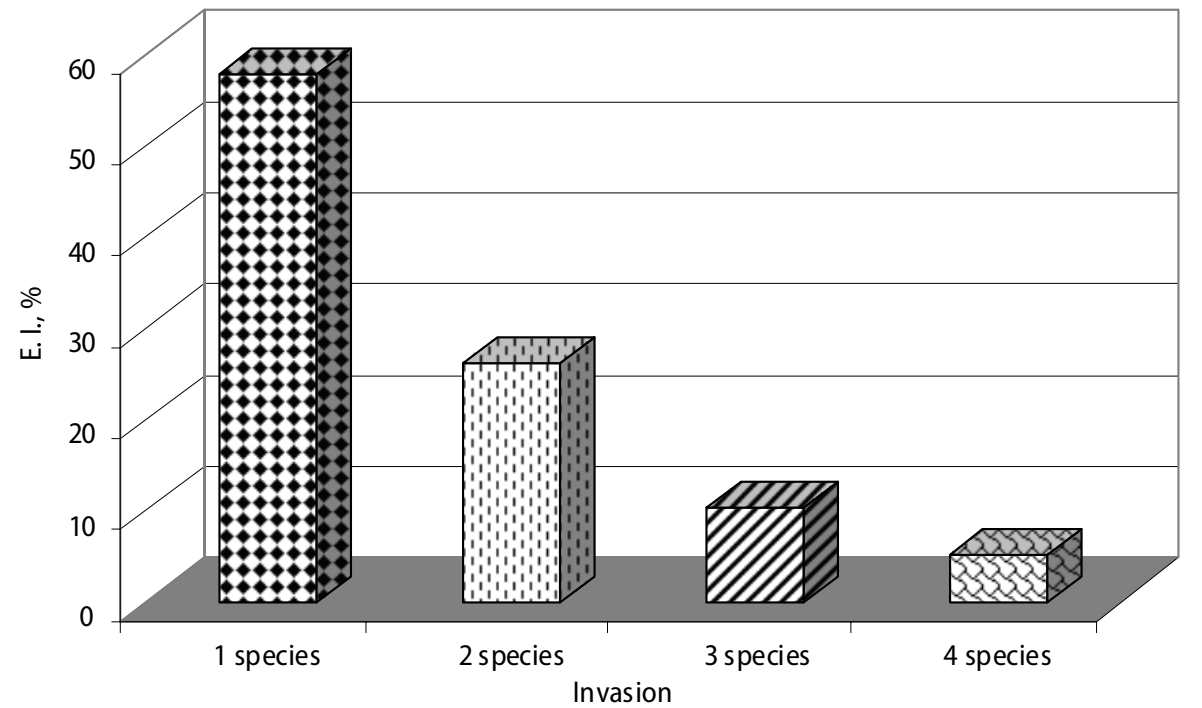

Figure 2

One- and multi-species Eimeria invasions in heifers studied

Auftreten einer bzw. mehrerer Eimeriaarten der untersuchten Färsen 
The coproscopic examination showed the heifers imported from the Netherlands to Poland to be infected by Cryptosporidium sp., found in $11.32 \%(n=12)$ of the individuals. The coproscopic examination showed the prevalence of Fasciola hepatica invasion in the heifers imported from the Netherlands to be $32.08 \%(n=34)$.

This study showed the mean prevalence of gastrointestinal nematodes in heifers imported to Poland from the Netherlands to be $55.66 \%(n=59)$. The presence of 6 gastrointestinal nematodes of the genera Ostertagia $(42,1 \%, n=25)$, Trichostrongylus $(21,4 \%$, $n=12)$, Cooperia $(31,7 \%, n=19)$, Capillaria $(1,4 \%, n=1)$, Nematodirus $(3,2 \%, n=2)$, and Oesophagostomum $(30,8 \%, n=18)$ was revealed. No lung-infesting nematodes were found.

\section{Discussion}

The heifers imported to the Czech Republic from France, Denmark, the Netherlands, and Germany showed the parasites to occur at a prevalence ranging from 91.2 to $100 \%$ (PAVLÁSEK 1995).

Among numerous parasites occurring in animals, particularly noteworthy are coccidia due to their wide distribution, independent of climatic conditions.

The coccidia species composition depends primarily on local environmental and breeding conditions (DAVIS and BROWMAN 1967). In their study on dairy cattle in the Netherlands, CORNELISSEN et al. (1995) found Eimeria in 16, 43, and $46 \%$ of the cows, heifers, and calves, respectively. The authors referred to identified E. bovis, E. aubernensis, E. ellipsoidalis, E. subspherica, E. zürni, E. alabamensis, E. canadensis, E. cylindrica, E. pellita, E. wyomingensis, E. bukidnonensis, and E. brasiliensis in the cattle they examined. The heifers proved to be most frequently supporting E. bovis (34.3\%) and E. aubernensis (18.9\%). To date, E. brasiliensis has not been isolated from cattle in Poland, although the protozoan has been reported from the Netherlands (CORNELISSEN et al. 1995).

PAVLÁSEK (1995), when studying heifers imported from Denmark and Germany, found Eimeria in 58. and $92.8 \%$ of the cows, respectively; the protozoans were dominated by oocytes of E. bovis, E. auburnensis, and E. zuerni.

ERNST et al. (1984) examined meat cattle (cows and calves) grazing in northern Georgia and isolated 12 and 10 Eimeria species from cows and calves, respectively. Eimeria bovis was the most frequent species in both calves $(72.5 \%)$ and cows $(10.2 \%)$. The study of BEJSOVEC et al. (1982) on cattle revealed the presence of protozoans such as Eimeria bovis (55.6\%) and E. zuerni (47,0\%), E. auburnensis (43,3\%), E. ellipsoidalis (39,4\%), E. cylindrica (25.2\%), E. subspherica (13.6\%), E. bukidnonensis (3.1\%), Isospora spp. (1.7\%), E. brasiliensis $(0.4 \%)$, and E. pellita $(0.08 \%)$.

The selected Western Pomeranian farms studied by PILARCZYK et al. (2002) showed coccidia prevalence in $5.5-12.0 \%$ of cows in small-scale farms and in $23.4 \%$ of the cows kept in a large-scale form. The cows proved to be infested by the following 6 coccidia species: E. bovis, E. aubernensis, E. zürni, E. elipsoidalis, E. subspherica, and E. cylindrica (PILARCZYK et al. 1999). CORNELISSEN et al. (1995) found heifers to be affected by invasions of 6 species.

PAVLÁSEK (1995) found Cryptosporidium muris in $4.5 \%$ of heifers imported from France and in $7.9 \%$ of heifers imported from Germany to the Czech Republic. As reported 
by PILARCZYK et al. (2002), calves and cows kept in small private farms in Western Pomerania were not affected by a Cryptosporidium $s p$. invasion. On the other hand, MAJEWSKA et al. (1998) found oocysts of Cryptosporidium sp. in 34.4\% of the cattle in the region of Wielkopolska (including $39.7 \%$ of calves and $6.6 \%$ of cows). The presence of Cryptosporidium sp. has been reflected from other countries as well, e.g., in $1.9 \%$ of the cattle in the US (FAYER et al. 2006), in 5\% in Mexico (MALDONA-CAMARGO et al. 1998), in $20 \%$ in Canada (OLSON et al. 1997), in 13\% in Sweden (KLINGENBERG 1992), and in $19.7 \%$ in Spain (QUILEZ et al. 1996).

The Netherlands is one of those European countries where liver fluke has been known for many years (MOLL et al. 2000), therefore it should be paid a particular attention when livestock imports are being carried out. In Poland, too, the liver fluke has been reported at various intensities - cows, the extent of infestation being dependent on time and area of study. In their 2001 study of selected Western Pomeranian cattle farms, PILARCZYK et al. (2002) showed the absence of a Fasciola hepatica invasion On the other hand, the prevalence of the parasite in North-Eastern Poland was as high as $11 \%$ (MICHALSKI et al. 1993, MICHALSKI and ROMANIUK 2000). Eggs of Fasciola hepatica were also found by PAVLÁSEK (1995) in 12 heifers imported from France to the Czech Republic. The prevalence of Fasciola hepatica in the heifers imported from the Netherlands should be regarded as high.

In his study on heifers imported to the Czech Republic, PAVLÁSEK (1995) recorded the presence of 9 gastrointestinal nematodes. Most frequent were representatives of the genera Ostertagia, Haemonchus and Trichostrongylus. In the study described by PILARCZYK et al. (2002) and carried out in selected Western Pomeranian farms, the gastrointestinal nematode prevalence in cows was found to range within $12.7-32.1 \%, 42.6 \%$ prevalence being revealed in a large-scale farm. The study reported by DÜWEL (1990) from Germany revealed gastrointestinal nematode eggs to be present in faeces of $60 \%$ of the ungulates, while ISTASSE et al. (1990) in Belgium recorded a $47.4 \%$ prevalence of infestation in dairy cows.

It was found that prevalence of coccidiosis in imported animals was generally comparable to that observed in Dutch cattle by CORNELISSEN et al. (1995). The data on prevalence of coccidiosis in Polish cattle are largely comparable with the level of infection in Dutch cattle. It is worth noting the high prevalence of fascioliasis (32.08\%) in imported cattle. In West Pomerania, fascioliasis has occurred sporadically in cattle in recent years. In imported cattle, the level of infection with gastrointestinal nematodes was high (55.66\%). In cattle from West Pomerania, the prevalence of gastrointestinal nematodes varied between 12.7 and $42.65 \%$ according to farm (PILARCZYK et al. 2002).

Summaring the prevalence of infestation with gastrointestinal parasites in the cattle imported to Poland from the Netherlands was very high. It is therefore purposeful that imported animals be subjected to mandatory examination for the presence of those parasites.

\section{References}

Agneessen SJ, Claerebout E, Dorny P, Borgsteede FH, Vercruysse J (2000) Nematode parasitism in adult dairy cows in Belgium. Vet Parasit 90, 83-92

Anonymous (1991) Basic laboratory methods in medical parasitology WHO Geneva 18 
Bejsovec J, Donát K (1982) Internal parasites in calves and heifers in a central rearing barn. Vet Med 27, 405-17

Borgsteede FH, Sol J, Van Uum A, De Haan N, Huyben R, Sampimon O (1998) Management practices and use of anithelminthics on dairy cattle farms in the Netherlands results of a questionnaire survey. Vet Parasit, 23-36

Borgsteede FH, Tibben J, Cornelissen JB, Agneessens J, Gaasenbeek CP (2000) Nematode parasites of adult dairy cattle in the Netherlands. Vet Parasit 89, 287-96

Cornelissen A, Verstegen R, Perie NM, Eysker M, Van Den Brand H, Lam T, Pijpers A (1995) An observational study of Eimeria species in housed cattle Dutch dairy farms. Vet Parasit 56, 1-3

Davis LR Browman GW (1967) Studies on experimental concurrent infections of dairy calves with coccidia and nematodes. J Protozool 14, 27

Distl $O$ (2001) Implications of health traits in breeding of dairy cattle. Arch Tierz 44, 365-80 [in German]

Düwel D (1990) Studies in ruminants on the incidence of eggs of gastrointestinal nematodes in faeces in relation to worm burden. Mitt Österr Gesell Tropenmed Parasit 12, 69-80

Ernst JV, Ciordia H, Stuedemann JA (1984) Coccidia in cows and calves on pasture in north Georgia (USA). Vet Parasit 15, 213-21

Fayer R, Santín M, Trout JM, Greiner E (2006) Prevalence of species and genotypes of Cryptosporidium found in 1-2-year-old dairy cattle in the eastern United States. Vet Parasit 135, 105-12

Gundłach J, Sadzikowski A (2004) Parasitology and Animal Parasites. PWRiL Warszawa [in Polish]

Górski P, Niżnikowski R, Strzelec E, Popielarczyk D, Gajewska A, Wedrychowicz H (2004a) Prevalence of protozoan and helminth internal parasite infections in goat and sheep flocks in Poland. Arch Tierz 47 $\mathrm{SI}, 43-9$

Górski P, Niżninowski R, Popielarczyk D, Strzelec E, Gajewska A, Wedrychowicz H (2004b) Natural parasitic infections in various breeds of sheep in Poland. Arch Tierz $47 \mathrm{SI}, 50-5$

Hilgenstock F, Hamann H, Rosenberge E, Götz K-U, Distl O (2006) Analysis of health traits in different lifetime classes in stationary progeny tested German Fleckvieh bulls. Arch Tierz 49, 222-23 [in German]

Istasse L, Chapaux P, Hanzen C, Antoine O, Losson B, Kafidi N, Leroy P, Bienfait JM (1990) Study of the effect of nutritional health and management factors on milk production and reproductive performance of dairy cattle. I. Methodology and results. Ann Med Vet 134, 27-33

Klingenberg K (1992) Enteropatogener hos kalvar pavisade med ett kommersiellt test SO SvenskVeterinart 12, 503-7

Majewska A, Werner A, Sulima P (1998) Prevalence of Cryptosporidium in livestock in Wielkopolska region. Wiad Parazytol 44, 471

Maldona-Camargo S, Atwill ER, Saltijeral-Oaxaca JA, Herrera-Alonso LC (1998) Prevalence of and risk factors for shedding of Cryptosporidium parvum in Holstein Friesian dairy calves in Central Mexico. Prev Vet Med 36, 95-107

Mekroud A, Benakhla A, Vignoles P, Rondelaud D, Dreyfuss G (2004) Preliminary studies on the prevalences of natural fasciolosis in cattle sheep and the host snail (Galba truncatula) in northeastern Algeria. Parasitol Res 92, 502-5

Michalski M, Gaca-Łagodzińska K, Brzeska E (1990) Extensity of Fasciola hepatica infection in 1980-1990 in the Olsztyn District. Weterynaria-Olsztyn 19, 47-56 [in Polish]

Michalski M, Romaniuk K (2000) Liver fluke (Fasciola hepatica L) in dairy cows in North-East Poland. Med Wet 56, 182-4 [in Polish]

Moll L, Gaasenbeek C, Vellema P, Borgsteede F (2000) Resistance of Fasciola hepatica against triclabendazole in cattle and sheep in The Netherlands. Vet Parasit 91, 153-8

Olson ME, Thorlakson CL, Deselliers L, Morck DW, Mcallister TA (1997) Giardia and Cryptosporidium in Canadian farm animals. Vet Parasit 68, 375-81

Pavlásek I (1995) Cryptosporidia and other endoparasites in heifers imported into the Czech Republic. Vet Med 40, 333-6

Pellerdy LP (1994) Coccidia and Coccidiosis. Akademiai Kiodo Budapest

Pilarczyk B, Balicka-Ramisz A, Prost M (1999) The dynamics of Eimeria spp infection in calves treated and untreated with Baycox. Med Wet 55, 523-6 [in Polish]

Pilarczyk B, Ramisz A, Jastrzębski G (2002) Internal parasites of cattle in select Western Pomerania farms. Wiad Parazytol 48, 383-90 [in Polish] 
Quilez J, Sanchez-Acedo C, Cacho E-DEL, Clavel A, Causape AC, Del-Cacho E (1996) Prevalence of Cryptosporidium and Giardia infections in cattle in Aragon (northeastern Spain). Vet Parasit 66 3-4, $139-46$

Ziomko I, Cencek T (1995) Outlive of laboratory diagnostic of farm animal parasites. Inst Weterynarii Puławy [in Polish]

Received 5 October 2007, accepted 23 February 2009.

Corresponding author:

BOGUMIŁA PILARCZYK, PhD

email: bogumila.pilarczyk@biot.ar.szczecin.pl

Department of Animal Hygiene and Prophylaxis, Agricultural University of Szczecin, ul. Doktora Judyma 6, 71-460 Szczecin, Poland 